DOI: 10.15393/j9.art.2012.349

Рима Ханифовна Якубова,
доктор филологических наук, профессор кафеедры русской титературы и издательского дела

филологического факультета, Башкирский государственный университет

(Уфа, Российская Федерация) irlxx@yandex.ru

\title{
ДИАЯОГИЧЕСКАЯ КОНВЕРГЕНЦИЯ БИБЛЕЙСКИХ И ЛИТЕРАТУРНЫХ ФАБУЛ В РОМАНЕ Ф. М. ДОСТОЕВСКОГО «ПОДРОСТОК»
}

Аннотация: В статье обсуждается проблема диалогической конвергенции библейских и литературных фабул в романе Ф. М. Достоевского «Подросток», исследуются вопросы творческого диалога, который ведет писатель с предшествующей традицией, а также синтеза в фабульном репертуаре этого романа библейских и литературных источников. Особое внимание уделяется отношению автора к библейской фабульной традиции и роли библейского подтекста в сюжетно-композиционной организации романа, выделен комплекс мотивов и образов, связывающих «Подросток» с ветхозаветным источником, дан сопоставительный анализ фабулы «Станционного смотрителя» А. С. Пушкина с фабулами «Униженных и оскорбленных» и «Подростка» Ф. М. Достоевского в общем контексте ветхозаветной традиции. В статье исследуется процесс трансформации классических фабул, вопросы их конвергенции и возрождения в романе «Подросток», что связывается с открытым конвергентным типом художественного сознания писателя.

Ключевые слова: фабула, мотив, конвергенция, прецедентный текст, рецепция, трансформация, интерпретация

B рукописных материалах к «Подростку» неоднократно встречаются замечания, которые фиксируют пристальный интерес Достоевского к фабульному завершению романа. Начиная работу над «Подростком», он пишет:

Но затем - ФАБУЛУ, ФАБУЛУ!, которую развивать страшно сжато, последовательно и неожиданно» 1 .

История юноши придумывается на ходу, но при этом художник вступает в большой диалог со сложившейся культурной традицией и тем самым создает мощный фабульный метатекст.

В диалоге Достоевского с культурой предшествующих эпох особое место, конечно же, занимает Библия. Исследователи и комментаторы «Подростка» неоднократно указывали на последовательное упоминание в этом романе ветхозаветных персонажей. В первую очередь, разумеется, это определяется тем, что сами романные 
герои соотносят свою жизнь с сюжетами из Библии. Так, Версилов, рассказывая сыну историю собственных взаимоотношений с «мамой» и Макаром Долгоруким, иронически сравнивает себя с царем Давидом, который соблазнил жену своего военачальника Урии:

Ну что, если 6 он закричал на весь двор, завыл, сей уездный Урия, - ну что бы тогда было со мной, с таким малорослым Давидом, и что бы я сумел сделать? (XIII, 107).

Т. А. Касаткина обратила внимание на то, что действие романа «Подросток» развивается все время на фоне истории дома Давидова, начиная с того, что Версилов сравнивает себя с Давидом, а Макара с Урией, и кончая историями Фамари и Ависаги $[5,9]$. В рукописных материалах старый князь Сокольский, надумавший жениться на Анне Андреевне Версиловой, вспоминает о царе Давиде, «который брал молодых красоток в свою постель, чтобы согреть свою старость» (XVI, 339).

Проблема использования ветхозаветных источников в «Подростке» уже была зафиксирована в исследовательской литературе $[11,55$-56], но до сих пор остаются открытыми вопросы о роли библейского подтекста в сюжетно-композиционной организации романа и об отношении автора к библейской фабульной традиции. Действительно, для чего автор так настойчиво соотносит Версилова с царем Давидом, в чем заключается смысл последовательного сближения литературного и библейского героев? Следует особо подчеркнуть, что это сопоставление возникает еще в подготовительных материалах к «Подростку», когда сам Версилов сравнивает свою историю с сюжетом о сунамитянке Ависаге и царе Давиде из Третьей книги Царств. В окончательном тексте историю царя Давида и Ависаги в связи с отношениями Версилова и «мамы» приводит их сын Аркадий в откровенном разговоре с Ламбертом:

Знаешь ты историю Ависаги, Ламберт, читал ее? - Нет, не помню; роман? пробормотал Ламберт. - О, ты ничего не знаешь, Ламберт! Ты страшно, страшно необразован... (XIII, 420).

То, что при характеристике «мамы» автор обращается к образу Ависаги - красивой девушки сунамитянки, из колена Исаахарова, избранной слугами Давида для прислуживания ему в старости, объясняется трансформацией в романе Достоевского связанного с этим библейским образом мотива жертвенного служения молодой девушки немощному старцу. Разумеется, в данном случае речь идет не о физиологическом возрасте, а о молодости и силе духа Софьи Андреевны, которая открыто приносит себя в жертву Версилову и пытается своим служением спасти его. Сам Версилов признается сыну, что часто говорил «маме» о жертвенности ее чувства:

Милая, я тебя мучаю и замучаю, и мне не жалко, пока ты передо мной; а ведь умри ты, и я знаю, что уморю себя казнью (XIII, 171). 
Библейский мотив Ависаги объединяет, как ни странно, Версилова и старого князя Сокольского. Эта аналогия, в свою очередь, отсылает читателя к сказочному сюжету о юной деве, принесенной в жертву дракону. Особо значимым представляется тот факт, что сам князь Сокольский в разговоре с Аркадием предлагает широкую амплитуду вариантов этого мотива - от поэмы о царе Давиде до альковной сцены в духе Поль де Кока (в рукописных материалах к роману звучит гораздо грубее - «сцена с грелкой»).

Более сложный комплекс мотивов образуется в романе благодаря другой библейской аллюзии, связанной с ветхозаветным сюжетом о Давиде, Урии и Вирсавии. В первую очередь, это мотив внезапно вспыхнувшего чувства и связанного с ним предательства. Как известно из Второй книги Царств, царь Давид, увидев с кровли своего дома купающуюся красивую женщину, воспылал к ней страстью и приказал своим слугам привести ее в царский дом. Это была Вирсавия, жена храброго полководца Урии Хеттеянина. Женщина «сделалась беременной» и послала известить об этом Давида. Царь попытался скрыть грех, призвав своего военачальника домой, но когда его план не осуществился (Урия не пошел домой, а спал у царских ворот), то он отпустил Урию на поле сражения с письмом Иоаву.

В письме он написал так: поставьте Урию там, где будет самое сильное сражение, и отступите от него, чтоб он был поражен и умер. Посему, когда Иоав осаждал город, то поставил он Урию на таком месте, о котором знал, что там храбрые люди. И вышли люди из города и сразились с Иоавом, и пало несколько из народа, из слуг Давидовых; был убит также и Урия Хеттеянин (2 Цар. 11:15-17).

После смерти Урии Вирсавия стала женой царя Давида.

Как и в библейской притче, в романе Достоевского совершается двойное предательство: Версилов соблазняет жену своего крепостного и тем самым, как признается преданный им Макар Долгорукий, «пронзает» его сердце. Конечно же, никто не отправляет Макара Долгорукого на верную смерть, наоборот, соблазнитель признается в своем грехе, даже просит прощения и призывает обманутого мужа стать судьей для согрешивших, но от этого предательство помещика по отношению к своему крепостному, за жизнь которого он несет ответственность, не становится менее драматическим. Странничество Макара - это своего рода отказ от жизни и ее радостей.

Другие мотивы, связывающие роман «Подросток» с ветхозаветным источником, содержатся в продолжении библейской истории. Пророк Нафан, посланный Господом, рассказывает царю Давиду притчу про богатого человека, у которого было много овец, но который отнял единственную овечку у бедняка, чтобы накормить странника. На вопрос разгневанного Давида о том, кто этот грешный человек, Нафан указывает на него самого:

Урию Хеттеянина ты поразил мечом; жену его взял себе в жену, а его ты убил мечом Аммонитян (2 Цар. 12:9). 
Бог все же простил покаявшегося Давида, но его преступление повлекло за собой роковые последствия:

И сказал Нафан Давиду: и Господь снял с тебя грех твой; ты не умрешь; но как ты этим делом подал повод врагам Господа хулить Его, то умрет родившийся у тебя сын (2 Цар. 12:13-14).

Как и было предсказано пророком, сын, рожденный Вирсавией от незаконной связи с Давидом, умер. В романе Достоевского незаконная связь Версилова и Софьи Андреевны также сопровождается смертью сына, но не первого, а третьего - последнего. Об этом Аркадий Долгорукий говорит в самом начале повествования:

Скажу лишь, что год спустя после Макара Ивановича явился на свете я, затем еще через год моя сестра, а затем уже лет десять или одиннадцать спустя - болезненный мальчик, младший брат мой, умерший через несколько месяцев (XIII, 13).

Упоминание об умершем младшем брате вносит особую трагическую ноту в рассказ о «случайном семействе», а также вновь отсылает читателя к ветхозаветному сюжету.

Герой романа Достоевского может быть соотнесен с библейским прообразом не только потому, что Версилов, как и царь Давид, наказан смертью сына за нарушение десятой заповеди Моисея, которая гласит:

Не желай жены ближнего твоего и не желай дома ближнего твоего, ни поля его, ни раба его, ни рабы его, ни вола его, ни осла его, ни всего, что есть у ближнего твоего (Втор. 5, 21).

Как написано в Ветхом Завете, в доме царя Давида совершились самые тяжкие внутрисемейные преступления - братоубийство, покушение на отцеубийство, инцест. Грехи отца обернулись грехами его детей.

Этот ветхозаветный мотив семейного греха, падшего на детей, также получает свое воплощение в романе Достоевского. Дочери Версилова Анна Андреевна и Лиза, сводные сестры, поневоле выступают в роли соперниц. К тому же последняя, которая ждет от молодого князя Сокольского ребенка, повторяет грешную судьбу своей матери. Узнав об этом, брат задает сестре самый страшный для нее и для себя вопрос:

Неужели ты не подумала, Лиза, что это - маме укор? Я всю ночь об этом промучился; первая мысль мамы теперь: «Это - потому, что я тоже была виновата, а какова мать - такова и дочь!» (XIII, 238).

Враждуют между собой и сыновья Версилова, тоже сводные братья. Но главное, что в роли непримиримых соперников выступают отец и сын. Семейство Версилова, как и дом царя Давида, сопровождают многочисленные несчастья, которые являются возмездием за преступление, совершенное главой семейства. 
Помимо фабулы о Давиде, Урии и Вирсавии, Достоевский заимствует из Ветхого Завета и продолжение этой истории. Если ориентироваться на библейскую традицию, то Аркадий Долгорукий - это тот самый сын, который должен был своей смертью искупить грех отца. Но Подросток расплачивается за отцовский грех иначе - чередой унижений, обид и бесчестия, а главное, «выброшенностью» из семьи. Логично будет предположить, что библейским прототипом Аркадия становится другой сын Вирсавии и Давида - Соломон:

И утешил Давид Вирсавию, жену свою, и вошел к ней и спал с нею: и она родила сына и нарекла ему имя: Соломон. И Господь возлюбил его (2 Цар. 12: 24).

Царство Давида было завещано его любимцу Соломону, который был младшим сыном и не являлся престолонаследником. Получить царство по смерти Амнона и Авессалома намеревался Адония, четвертый сын Давида, которого он родил от Аггифы, но на престол восходит любимец Давида Соломон. В романе Достоевского неоднократно подчеркивается, что именно Аркадию суждено стать наследником и Версилова, и странника Макара, именно ему предначертано соединить в себе ум одного и душу другого.

Глубоко символично, что старый князь Сокольский, мечтая о женитьбе на Анне Андреевне, путает песни царя Соломона с библейским рассказом о старости царя Давида:

David, Salomon, все это кружится у меня в голове - кавардак какой-то (XIII, 255-256).

Объединение в сумеречном сознании старого князя образов Давида и Соломона не только напоминает читателю о сыне Давида и Вирсавии, но и подчеркивает сходство Версилова и Аркадия, отца и сына, которые страстно влюбляются в одну и ту же женщину - Катерину Николаевну Ахмакову.

Еще Л. П. Гроссман обратил внимание на то обстоятельство, что в своей творческой работе Достоевский никогда не стеснял себя подлинными признаками прототипа:

...ему нужна была не определенная конкретная фигура во всех ее особенностях, а лишь ее художественная выразительность $[2,223]$.

Т. А. Касаткина в статье, посвященной авторской идее в структуре повествования «Подростка», указывает на то, что можно обнаружить множество аналогий между текстом романа и Книгой Премудрости Соломона $[5,5]$. Как известно, с именем царя Соломона и в библейской, и в общекультурной традиции связаны два представления - о несметном богатстве и мудрости. Знаковым является упоминание Аркадием этого библейского персонажа, когда он излагает суть своей ротшильдовской теории, объясняя, как он станет богатым и могущественным:

Ума, что ли, тут так много надо? Что за Соломонова такая премудрость! (XIII, 70). 
Но история самого рассказчика открывает очевидную истину: чтобы «душу паука» победила «жажда благообразия», действительно необходимо различать добро и зло и иметь мудрое сердце. Это ровно то, о чем просит Соломон у Господа:

...и ныне, Господи Боже мой, Ты поставил раба Твоего царем вместо Давида, отца моего; но я отрок малый, не знаю ни моего выхода, ни входа... даруй же рабу Твоему сердце разумное, чтобы судить народ Твой и различать, что добро и что зло; ибо кто может управлять этим многочисленным народом Твоим? И благоугодно было Господу, что Соломон просил этого. И сказал ему Бог: за то, что ты просил этого и не просил себе долгой жизни, не просил себе богатства, не просил себе душ врагов твоих, но просил себе разума, чтоб уметь судить, - вот, Я сделаю по слову твоему: вот, Я даю тебе сердце мудрое и разумное, так что подобного тебе не было прежде тебя, и после тебя не восстанет подобный тебе; и то, чего ты не просил, Я даю тебе, и богатство и славу, так что не будет подобного тебе между царями во все дни твои; и если будешь ходить путем Моим, сохраняя уставы Мои и заповеди Мои, как ходил отец твой Давид, Я продолжу и дни твои (3 Цар. 3:7-14).

Художественная выразительность обращения Достоевского к образу библейского царя, который считался олицетворением мудрости, неизмеримо усиливается, соединяясь со сказочной фабулой об обездоленном младшем брате, получившем «знание, художество, миф и обряд», т. е. право стать нематериальным наследником древнего княжеского рода.

С библейской историей об Урии Хеттеянине связана, как уже говорилось выше, фабула об ограбленном бедняке, которая, несомненно, играет в романе Достоевского сюжетообразующую роль (богач, укравший единственную овцу у бедняка (2 Цар. 12: 9)) и которая переосмысляется Достоевским через опосредованный литературный диалог со «Станционным смотрителем» А. С. Пушкина. В статье «Еще об одном литературном и историческом прототипе Версилова. Роман Ф. М. Достоевского «Подросток»» Г. Мондри указывает на то, что именно «Повести Белкина» Пушкина были в центре внимания Достоевского, мучительно искавшего сюжет для «Подростка» $[7,105]$. В частности, она обращает внимание на общность мотивов пушкинской повести «Выстрел» и романа Достоевского и таким образом указывает на Сильвио как одного из возможных прототипов Версилова.

В филологической науке существует ряд ярких и глубоких работ, в которых рассматриваются разные аспекты воздействия повести А. С. Пушкина «Станционный смотритель» на сюжетно-композиционную организацию произведений Ф. М. Достоевского. Но, как правило, речь в них идет о «Бедных людях» или «Униженных и оскорбленных». Еще М. С. Альтман, подробно исследовав общий для «Станционного смотрителя» и «Униженных и оскорбленных» сюжет о девушке, покинувшей отчий дом для любимого, убедитель- 
но доказал зависимость романа Достоевского от повести Пушкина [1, 23-32]. Среди множества трудов, в которых затрагивалась проблема рецепции писателем пушкинской повести, можно также выделить исследование Р. Г. Назирова, которое напрямую обращено к фабульному репертуару русской литературы и посвящено вопросу о трансформации пушкинских и гоголевских фабул в творчестве русских классиков. Так, в «Станционном смотрителе» и «Медном всаднике» этот исследователь обнаружил начало традиции художественного воплощения в русской литературе «фабулы об ограблении бедняка», которую затем воплотил в «Шинели» Н. В. Гоголь.

Назиров указал на то, что Достоевский в «Бедных людях» обращается к той же пушкинской фабуле, которая, естественно, претерпевает определенную трансформацию:

Опять ограбление бедняка. Отметим градацию: у Самсона Вырина отняли дочь, у Евгения - невесту, у Башмачкина — шинель, у Макара Девушкина — тайно любимую девушку, смысл всей его жизни $[8,376]$.

Исследователь обратил внимание на то, что к фабуле об ограблении бедняка Достоевский возвращался на протяжении своего творческого пути дважды: в «Униженных и оскорбленных» (Иеремия Смит и Ихменев оба лишились дочерей) и в «Преступлении и наказании» (конкретизация обозначенной фабулы во второй сюжетной линии - в драме семьи Мармеладовых).

Но думается, что предложенный Назировым литературоведческий сюжет нуждается в существенном дополнении, так как, завершив фабульную традицию об ограблении бедняка «Преступлением и наказанием», он не учел того факта, что Достоевский обращается к пушкинской фабуле и на более позднем этапе своего творчества в романе «Подросток». Более того, в этом произведении автор не только трансформирует и концептуально переосмысляет сюжет «Станционного смотрителя», но и прямо напоминает о первоисточнике - библейской истории о Давиде, Урии и Вирсавии.

Сопоставление двух главных для фабулы Пушкина и Достоевского образов (отца и мужа) следует начать с замечания о том, что Макар Долгорукий выступает по отношению к Софье Андреевне в роли мужа-отца. Во-первых, он на тридцать с лишним лет старше своей невесты. Этот художественный факт намеренно подчеркнут автором. Во-вторых, рассказ странника Макара о том времени, когда Софья еще «на ножках не стояла», а он с ней нянчился, содержит именно отцовские мотивы:

Сказки я тебе потом рассказывал, Софья Андреевна; до сказок ты у меня большая была охотница; часа по два на коленях у меня сидит - слушает. В избе-то дивятся: «Ишь к Макару как привязалась». А то унесу тебя в лес, отыщу малиновый куст, посажу у малины, а сам тебе свистульки из дерева режу. Нагуляемся и назад домой на руках несу - спит младенчик (XIII, 329-330). 
B-третьих, и это особенно важно в контексте рассуждений о фабульном диалоге, девушка завещана Долгорукому ее умирающим отцом, о чем Подросток подробно рассказывает читателю:

Софья Андреева (эта восемнадцатилетняя дворовая, то есть мать моя) была круглою сиротою уже несколько лет; покойный же отец ее, чрезвычайно уважавший Макара Долгорукого и ему чем-то обязанный, тоже дворовый, шесть лет перед тем, помирая, на одре смерти, говорят даже, за четверть часа до последнего издыхания, так что за нужду можно бы было принять и за бред, если бы он и без того не был неправоспособен, как крепостной, подозвав Макара Долгорукого, при всей дворне и при присутствовавшем священнике, завещал ему вслух и настоятельно, указывая на дочь: «Взрасти и возьми за себя» (XIII, 9).

Обращает на себя внимание глагол «взрасти», который подразумевает передачу умирающим своих отцовских функций другу.

На соотнесение «Подростка» с фабулой «Станционного смотрителя» указывает и то, что в истории взаимоотношений Версилова, Софьи и Макара Долгорукого речь идет именно об ограблении бедняка, о чем прямо говорится в тексте романа:

А человеку, который приехал с «Антоном Горемыкой», разрушать, на основании помещичьего права, святость брака, хотя и своего дворового, было бы очень зазорно перед самим собою, потому что, повторяю, про этого «Антона Горемыку» он еще не далее как несколько месяцев тому назад, то есть двадцать лет спустя, говорил чрезвычайно серьезно. Так ведь у Антона только лошадь увели, а тут жену! (выделено мной. - Р. Я.) (XIII, 10-11).

Таким образом, сам рассказчик почти напрямую указывает на литературные источники давней истории, то есть на те тексты, в которых речь идет об ограблении «горемык». К тому же указания на прецедентный текст обнаруживаются как в отдельных художественных деталях, которые автор «Подростка» заимствует из «Станционного смотрителя» (Самсон Вырин учит детишек «дудочки вырезывать», а Макар Долгорукий «свистульки из дерева» режет для маленькой девочки), так и в прямом цитировании Достоевским пушкинского текста, на что мне уже приходилось указывать в одной из своих статей (см. об этом: [10]).

Переосмысляется в романе Достоевского и мотив отступных, которые в обеих историях предлагаются ограбленному бедняку. Если станционный смотритель с негодованием бросает деньги на землю и лишь потом, спохватившись, хочет их подобрать, то Макар Долгорукий не отказывается от трех тысяч, предложенных ему Версиловым в качестве отступных. Этот поступок и, главное, следующие действия «ограбленного бедняка» приводят Версилова в недоумение, о чем он прямо заявляет Аркадию:

Не понимаю, зачем страннику столько собственных денег... деньги такая светская вещь... (XIII, 108).

Вполне закономерным представляется вопрос: для чего зрелому писателю понадобилось вновь возвращаться к фабуле, которая уже 
была использована им в «Бедных людях» и «Униженных и оскорбленных»? Ответ на него можно найти у самого романиста, который в письме жене из Эмса в июне 1874 г., т. е. в период работы над «Подростком», утверждал, что его по-прежнему завораживают пушкинские произведения:

...до сих пор читал только Пушкина и упивался восторгом, каждый день нахожу что-нибудь новое (XXIX, 331).

Упиваясь восторгом, Достоевский, с одной стороны, вступает в литературный диалог со своим предшественником, а с другой обнаруживает то, что скрыто в подтексте пушкинской повести. Ранее упоминалось о том, как «странно» поступил Макар Долгорукий с отступными, которые ему предложил Версилов. Это, конечно же, сознательная полемика с пушкинским текстом. Более того, обесчещенным в романе Достоевского выглядит не обманутый муж (отец), а соблазнитель. Версилов, как он впоследствии рассказывает сыну, попытался после своего поступка «с необыкновенной прямотой» объясниться с Долгоруким и предложил ему разные варианты выхода из сложившейся ситуации, но был обескуражен упорным молчанием своего дворового.

Минский воспринимает (пусть даже совершенно несправедливо) Самсона Вырина как разбойника, который хочет его зарезать, Версилов же, наоборот, обнаруживает в страннике Макаре необыкновенную почтительность:

А главное - почтительность, эта скромная почтительность, именно та почтительность, которая необходима для высшего равенства, мало того, без которой, по-моему, не достигнешь и первенства. Тут именно, через отсутствие малейшей заносчивости, достигается высшая порядочность и является человек, уважающий себя несомненно и именно в своем положении, каково бы оно там ни было и какова бы ни досталась ему судьба (XIII, 108-109).

С точки зрения переосмысления Достоевским пушкинской фабулы особое значение приобретают слова о человеке, который уважает себя именно в своем положении, какая бы ему ни досталась судьба. Макар Долгорукий, в отличие от Самсона Вырина, смиренно и почтительно принимает свою судьбу, свое положение. Это означает, если воспользоваться классификацией Назирова, что автор «Подростка» совершает переакцентировку пушкинской фабулы с кардинальной заменой ее развязки. Глубоко символична в этом отношении характеристика Версиловым своего бывшего дворового:

...этот Макар Иванович был нечто совсем другое... (XIII, 107).

М. С. Альтман, сопоставляя фабулы «Станционного смотрителя» и «Униженных и оскорбленных», возводит письмо старика Ихменева к несуществующей записке Самсона Вырина, той самой записке, под 
предлогом которой отец хочет увидеть собственную дочь. В «Подростке» этот мотив подвергается коренной трансформации: именно с помощью писем Макар Долгорукий поддерживает связь со своим разрастающимся семейством. Странник Достоевского не только смиряется со своей утратой, но и продолжает издалека служить поддержкой для людей, причинивших ему глубокие страдания. Назиров указал на то, что доминантным мотивом фабулы об ограблении бедняка является бессильный бунт героя против необоримых обстоятельств. В романе «Подросток» мотив бессильного бунта вытесняется мотивом милосердия и сострадания. Парадокс фабульной трансформации заключается в том, что эти чувства проявляют не те, кто обездолил бедняка, а сам ограбленный, т. е. в рассматриваемой типологической модели он уже не объект, а субъект действия.

Напомню еще раз, что Версилов при воспоминании об эпизоде своего объяснения с Макаром Долгоруким «умирает от стыда» и сравнивает себя с малорослым Давидом, которого мог легко растерзать уездный Урия.

Достоевский переосмысляет и преобразует как пушкинскую фабулу, так и библейскую историю о Давиде, Вирсавии и Урии. К тому же он синтезирует в своем романе ветхозаветный, литературный и евангельский тексты. Не следует упускать из виду, что пушкинский текст полемичен по отношению к приводимой в Евангелии от Луки притче о блудном сыне, притче, которая учит добродетелям покаяния и про щения. Достоевский, реактивируя в «Подростке» пушкинскую фабулу об ограблении бедняка и обнаруживая скрытые смыслы в пушкинском произведении, воспроизводит и евангельский подтекст этой фабулы - мотив прощения и смирения. Очевидно, что и Самсон Вырин, и Макар Долгорукий испытывают жалость к согрешившим женщинам. Но если пушкинский герой не в состоянии примириться с тем, что его грешная дочь может быть счастлива, то герой Достоевского прощает свою грешную жену-дочь, принимает ее грех на себя, что подтверждают его слова, сказанные незадолго до смерти:

Посему и ты, Софья, не смущай свою душу слишком, ибо весь твой грех мой, а в тебе, так мыслю, и разуменье-то вряд ли тогда было, а пожалуй, и в вас тоже, сударь, вкупе с нею, - улыбнулся он с задрожавшими от какой-то боли губами, - и хоть мог бы я тогда поучить тебя, супруга моя, даже жезлом, да и должен был, но жалко стало, как предо мной упала в слезах и ничего не потаила... ноги мои целовала (XIII, 331).

В данном случае уместно вспомнить, что при сравнении «Станционного смотрителя» с «Униженными и оскорбленными» Альтман обратил внимание на черту, которая объединяет двух отцов, Самсона Вырина и старика Ихменева. Это - невозможность про- 
стить дочь, покинувшую отца ради обольстителя и посмевшую быть при этом счастливой:

Ихменев, конечно, желает счастья своей дочери, но это счастье «вообще», а вот в частности, в данной ситуации, он предпочел бы даже ее несчастье... Достоевский, со свойственным ему беспощадным реализмом, показывает, что и родительская любовь имеет предел $[1,26]$.

Тот же исследователь отметил, что идея о том, можно ли простить счастливого, заложенная в подтексте пушкинской повести, отчетливо формулируется и вербально закрепляется в романе «Идиот» в словах князя Мышкина, обращенных к несчастному Ипполиту:

Пройдите мимо нас и простите нам наше счастье (VIII, 591).

Рассуждения Альтмана требуют, на мой взгляд, логического продолжения. Завершением намеченного исследователем метасюжета, в котором художественные тексты, свои и чужие, становятся для Достоевского предметом мощнейшей рефлексии и диалога, становится кардинальное переосмысление пушкинской фабулы об ограблении бедняка в романе «Подросток». Переосмысление, которое, как уже говорилось, одновременно обнаруживает скрытые смыслы пушкинской повести.

В истории Макара Долгорукого, который сознательно отказывается от бунта, проходит мимо тех, кто его ограбил, и прощает им их счастье, объединяется и то, что скрыто в подтексте пушкинской повести, и то, что прямо сформулировано в словах князя Мышкина. Таким образом, напутствуя перед смертью Лизу и Аркадия, напоминая Версилову о его "дворянском слове» обвенчаться с Софьей Андреевной в случае ее вдовства, Макар Долгорукий выступает уже не в роли обманутого мужа, а в роли любящего отца, который не только способен прощать, но и остается нравственной опорой для своих заблудших детей.

Как пишет Н. С. Изместьева, «Макар Иванович Долгорукий, по сути, воплощает притчу о пастыре и заблудшей овце» $[3,165]$. С уходом странника начинается раздвоение Версилова, который теряет нравственные ориентиры и опору. В подготовительных материалах содержатся слова Макара Ивановича, в которых он определяет роль человека в жизни окружающих его людей:

Пуще всего собственным делом служи. Нет сильнее, когда собственным делом укажешь... Чем и живет человек, как не добрым примером. <...> Освяти себя, всем послужишь: миру светя (XVI, 142).

Достоевский, реактивируя пушкинскую фабулу, не только заменяет развязку, но и совершает инверсию субъекта и объекта действия: Макар Долгорукий воспринимает себя не ограбленным (это 
взгляд Версилова), а тем, кто сам отказывается от счастья и отдает его. Позиция странника выражена в его размышлениях о «пустынножительстве»:

То ли у Христа: «Поди и раздай твое богатство и стань всем слуга». И станешь богат паче прежнего в бессчетно раз; ибо не пищею только, не платьями ценными, не гордостью и не завистью счастлив будешь, а умножившеюся бессчетно любовью. Уж не малое богатство, не сто тысяч, не миллион, а целый мир приобретешь! (XIII, 311).

В контексте фабулы об ограблении бедняка эти слова приобретают символический смысл. Макар Долгорукий живет в соответствии с христианскими заповедями, поэтому, какая бы ни досталась этому человеку судьба, он вызывает не сострадание, а глубочайшее уважение.

Таким образом, Достоевский через пушкинский сюжет возвращается к ветхозаветной истории о Давиде, ограбившем Урию, и тем самым дарит этой истории новую жизнь - его Урия продолжает жить как персонифицированная совесть тех, кто согрешил.

Отталкиваясь от ветхозаветной библейской и литературной (в данном случае пушкинской) фабул об ограбленном бедняке, Достоевский полностью их переосмысляет, потому что нельзя ограбить того, кто сам отдает и способен на жертвенную любовь и смирение. В Евангелии от Луки, которое цитирует Макар Долгорукий и которое по просьбе матери в день его похорон читает Аркадий Долгорукий, говорится о том, что тот, кто раздаст на земле свое богатство и станет всем слуга, «будет иметь сокровище на небесах» (Лк. 18:22). Макар Долгорукий не может изменить мир, вернуть разрушенную идиллию, но его пример наполняет жизнь окружающих светом. Урия Достоевского не только прощает, но и своим смирением пытается спасти тех, кто его предал.

В романе «Подросток» происходит встреча-диалог нескольких источников: библейских и литературных. Получается, что каждый из героев существует в пределах тех фабул, с которыми он сам соотносит свою жизнь. Версилов воспринимает свой поступок через историю Давида и Урии, Аркадий пытается осмыслить историю отца через сюжет пушкинской повести, а Макар Долгорукий выстраивает свою жизнь с опорой на евангельский текст. Автор включает фабульную рецепцию персонажей в широкий культурный контекст. Более того, Достоевский не просто трансформирует фабулы, а вдыхает в них новую жизнь, так как его герои живут, соизмеряя себя с библейскими и литературными героями. Искусство слова - это система координат их жизни. Примеряя на себя чужие истории, герои Достоевского соотносят себя с героями прошлого, мыслят на уровне художественного завершения своих историй. Дело не только и не столько в книжности 
героев, сколько в том, что они не представляют своего существования вне эстетической деятельности и вне диалога с Библией и литературой. Таким образом, в романе происходит встреча-конвергенция множества разнородных фабул.

Следует обратить особое внимание на то, что именно пушкинский текст связывает ветхозаветный источник с Евангелием. В. И. Тюпа, анализируя «Маленькие трагедии» Пушкина, пишет о такой особенности авторского сознания, как «диалогическое сопряжение двух взаимоотталкивающихся типов сознания в поле третьего сознания» $[9,174]$. Как указывает исследователь, это качество духовного строя Пушкина позволило Е. А. Маймину увидеть в «драматических сценках» Пушкина истоки полифонического романа Достоевского [6]. Если продолжить рассуждения В. И. Тюпы и воспользоваться его терминологией, то в отношении Подростка к миру можно обнаружить предельно сложную коллизию разных сознаний: от уединенного и авторитарного - до конвергентного, которое лежит в основе свободной личности - художника и читателя.

В своем романе Достоевский на разных уровнях текста отстаивает то, что является сущностью его художественности, - диалогическую конвергенцию разнородных фабул: несомненно, что отрефлексированность этой авторской позиции находит свое художественное воплощение в творческом становлении Аркадия Долгорукого.

Следует иметь в виду, что Достоевский в 70-е гг. интенсивно рассуждал об опасности обособления. Коити Итокава совершенно справедливо связал статью «Обособление», вышедшую в мартовском «Дневнике писателя» 1876 г., с романом «Подросток» [4]. Фабульная конвергенция свидетельствует о том, что Достоевский пытался преодолеть «отсутствие в обществе духовно-нравственного единства», «распад его на разномыслящие группы» в том числе и художественным строем своего романа, провозглашая принцип конвергентного сознания, которое активно включает в себя чужие сознания и художественные миры.

\section{Примечания}

Достоевский Ф. М. Полн. собр. соч.: В 30 т. Л.: Наука. 1972-1990. Т. 16. С. 48. Далее это издание цитируется в тексте с указанием номера тома римскими и страницы арабскими цифрами.

\section{Список литературы}

1. Альтман М. С. Достоевский. По вехам имен. Саратов: Изд-во Саратовского университета, 1975. 309 с. 
2. Гроссман Л. П. Собрание сочинений в 5 томах. М.: «Современные проблемы», 1928. Т. II. Вып. 2: Творчество Достоевского. 335 с.

3. Изместьева Н. С. «Слово творящее» в романе «Подросток» // Роман Ф. М. Достоевского «Подросток»: возможности прочтения. Коломна: КГПИ, 2003. C. $159-168$.

4. Итокава К. Обособление в «Подростке» // Роман Ф. М. Достоевского «Подросток»: возможности прочтения. Коломна: КГПИ, 2003. С. 82-86.

5. Касаткина Т. А. Роман Ф. М. Достоевского «Подросток»: идея автора в повествовании героя // Три века русской литературы. Актуальные аспекты изучения. М.; Иркутск, 2003. Вып. 3. С. 3-13.

6. Маймин E. А. Полифонический роман Достоевского и пушкинская традиция // Культурное наследие Древней Руси. М.: Наука, 1976. С. 312-315.

7. Мондри Г. Еще об одном литературном и историческом прототипе Версилова. Роман Ф. М. Достоевского «Подросток» // Dostoyevsky studies, 1985, vol. 6, pp. $103-112$.

8. Назиров Р. Г. Традиции Пушкина и Гоголя в русской прозе. Сравнительная история фабул // Назиров Р. Г. О мифологии и литературе, или Преодоление смерти. Исследования разных лет. Уфа: Уфимский полиграфкомбинат, 2010. C. $358-403$.

9. Тюпа В. И. Опыт драматических изучений А. С. Пушкина // Тюпа В. И. Анализ художественного текста. М.: Изд. Центр «Академия», 2006. С. 161-169.

10. Якубова P. X. Трансформация пушкинской фабулы об ограблении бедняка в романе Ф. М. Достоевского «Подросток» // Три века русской литературы: Актуальные аспекты изучения. М.; Иркутск: ФБГОУ ВПО «Восточно-Сибирская государственная академия образования», 2011. Вып. 25. С. 187-195.

11. Якубович И. Д. Поэтика ветхозаветной цитаты и аллюзии у Достоевского: бытование и контекст // Достоевский. Материалы и исследования. СПб., 2005. T. 17. C. $42-60$.

\title{
Rima Hanifovna Yakubova \\ Doctor of Philology, Professor, Department of Russian Literature and Publishing, Department of Philology, Bashkir State University (Ufa, Russian Federation) irlxx@yandex.ru
}

\section{DIALOGIC CONVERGENCE OF BIBLICAL AND LITERARY FABULAS IN “THE ADOLESCENT” BY F. M. DOSTOEVSKY}

\begin{abstract}
The article discusses the issue of dialogic convergence of biblical and literary fabulas in The Adolescent by Fedor Dostoevsky. We also examine the issue of the author's creative dialogue with the previous traditions, and the synthesis of biblical and literary sources in the novel's fabula. A special emphasis is made on the author's attention to biblical fabula tradition and the role of biblical subtext in the plot of the novel. We have outlined a set of images and motifs which link The Adolescent with its source in the Old Testament and provide a comparative analysis of the fabulas in Pushkin's The Station Master and Dostoevsky's Humiliated and Insulted and The Adolescent within the general context of the Old Testament tradition. The article examines the transformations of classical fabulas, their convergence and resurgence in The Adolescent thanks to the open, convergence-oriented type of artistic consciousness that we find in Dostoevsky.

Keywords: fabula, motif, convergence, precedent text, reception, transformation, interpretation
\end{abstract}




\section{References}

1. Altman M. S. Dostoyevsky. Po vekham imen [Dostoyevsky. Milestones for Names]. Saratov, Saratov State University Publ., 1975. 309 p.

2. Grossman L. P. Sobranie sochineniy: $v 5$ tomakh [Collected works: in 5 Vol.]. Moscow, Sovremennye problemy Publ., 1928. Vol. 2, issue 2: Tvorchestvo F. M. Dostoyevskogo [Fyodor Dostoyevsky's Creativity]. 335 p.

3. Izmestyeva N. S. «Slovo tvoryashchee» v romane «Podrostok» ["The Creative Word" in Fyodor Dostoyevsky's Novel "The Adolescent (The Raw Youth)"]. Roman F. M. Dostoyevskogo «Podrostok»: vozmozhnosti prochteniya [Fyodor Dostoyevsky's Novel "The Adolescent (The Raw Youth)": Possible Reading Interpretations]. Kolomna, Komi State Pedagogical Institute Publ., 2003, pp. 159-168.

4. Itokava K. Obosoblenie v «Podrostke» [Theme of Separation in Fyodor Dostoyevsky's Novel “The Adolescent (The Raw Youth)"]. Roman F. M. Dostoyevskogo "Podrostok»: vozmozhnosti prochteniya [Fyodor Dostoyevsky's Novel "The Adolescent (The Raw Youth)": Possible Reading Interpretations]. Kolomna, Komi State Pedagogical Institute Publ., 2003, pp. 82-86.

5. Kasatkina T. A. Roman F. M. Dostoyevskogo «Podrostok»: ideya avtora v povestvovanii geroya [Fyodor Dostoyevsky's Novel “The Adolescent (The Raw Youth)": Author's Idea in the Story of the Character]. Tri veka russkoy literatury. Aktualnye aspekty izucheniya [Three Centuries of Russian Literature: Actual Aspects of the Study]. Moscow; Irkutsk, 2003, issue 3, pp. 3-13.

6. Maimin E. A. Fyodor Polifonicheskiy roman Dostoyevskogo i pushkinskaya traditsiya [Dostoyevsky's Polyphonic Novel and Pushkin Tradition]. Kulturnoe nasledie Drevney Rusi [The Cultural Heritage of Old Russia]. Moscow, Nauka Publ., 1976, pp. $312-315$.

7. Mondri G. Eshche ob odnom literaturnom i istoricheskom prototipe Versilova. Roman F. M. Dostoyevskogo «Podrostok» [Once Again on the Literary and Historical Prototype of Versilov. Fyodor Dostoyevsky's Novel "The Adolescent (The Raw Youth)"]. Dostoyevsky Studies, 1985, vol. 6, pp. 103-112.

8. Nazirov R. G. Traditsii Pushkina i Gogolya v russkoy proze. Sravnitelnaya istoriya fabul [Pushkin and Gogol Traditions in Russian Prose. Comparative History of the Story Lines]. Nazirov R. G. O mifologii i literature, ili Preodolenie smerti. Issledovaniya raznykh let ["The Mythology and Literature, or the Overcoming of Death. Studies of Different Years" by R. Nazirov]. Ufa, Ufimsky poligrafkombinat Publ., 2010, pp. 358-403.

9. Tyupa V. I. Opyt dramaticheskikh izucheniy A. S. Pushkina [Dramatic Study Experience of Alexander Pushkin's Art Work]. Tyupa V. I. Analiz khudozhestvennogo teksta ["Analytics of the Artistic Text" by Valery Tyupa]. Moscow, Akademiya Publ., 2006, pp. 161-169.

10. Yakubova R. Kh. Transformatsiya pushkinskoy fabuly ob ograblenii bednyaka v romane F. M. Dostoyevskogo «Podrostok» [Transformation of Alexander Pushkin's Story Line of Poor Man Robbery in Dostoyevsky's Novel "The Adolescent (The Raw Youth)"]. Tri veka russkoy literatury: Aktualnye aspekty izucheniya [Three Centuries of Russian Literature: Actual Aspects of the Study]. Moscow; Irkutsk, The East Siberian State Academy of Education Publ., 2011, issue 25, pp. 187-195.

11. Yakubovich I. D. Poetika vetkhozavetnoy tsitaty i allyuzii u Dostoyevskogo: bytovanie i kontekst [Poetics of the Old Testament Quotations and Allusions in Fyodor Dostoyevsky's Works: Existence and Context]. Dostoyevsky. Materialy i issledovaniya [Dostoyevsky: Materials and Research]. Saint-Petersburg, Nauka Publ., 2005, vol. 17, pp. 42-60. 